\title{
Evaluation of some functional properties of purple corn (Zea mays L.) dye, during its processing at pilot scale.
}

\author{
Luis E. Napan, Bs ${ }^{1}$, Franco F. Vietti-Guzmán, Bs ${ }^{1}$, Erick Alvarez-Yanamango, Eng ${ }^{1}$, y Fredy Huayta, Msc ${ }^{1}$, \\ ${ }^{1}$ Pontificia Universidad Católica del Perú, Grupo de Investigación de Tecnología y Procesos Agroindustriales (ITEPA), Perú, \\ lnapant@pucp.edu.pe,ffvietti@pucp.pe,erick.alvarez@pucp.pe,fhuayta@pucp.edu.pe
}

\begin{abstract}
The present research aimed the evaluation of changes in functional properties during processing of purple corn dye extracted of its cob by solid-liquid extraction, then concentration and spray-dried in order to obtain a dye powder. The test performed were determination of Total Anthocynins (TA), Total Phenolic Content (TPC), and Antioxidant Capacity (AC) by ABTS method. Results obtained were TA content of 125,76 \pm $1,23 \mathrm{mg} \mathrm{TA} / \mathrm{g} \mathrm{DM}$, TPC of $127.47 \pm 0.59 \mathrm{mg} \mathrm{GAE} / \mathrm{g} \mathrm{DM}$, ABTS EC50 of $72.15 \pm 1.16 \mu \mathrm{g} \mathrm{TE} / \mathrm{g}$ (water-methanol extract) in purple corn cob characterization; in purple corn cob aqueous extract were TA content of $0.53 \mathrm{mg} \mathrm{TA} / \mathrm{ml}, 1.81 \mathrm{mg} \mathrm{GAE} / \mathrm{ml}$, $787.17 \mu \mathrm{g} \mathrm{TE} / \mathrm{ml}$; and after concentration $\mathrm{TA}$ content of $0.62 \mathrm{mg}$ $\mathrm{TA} / \mathrm{ml}, 2.26 \mathrm{mg} \mathrm{GAE} / \mathrm{ml}, 2471.77 \mu \mathrm{g} \mathrm{TE} / \mathrm{ml}$; and for purple corn dye powder were TA content of $0.37 \mathrm{mg} \mathrm{TA} / \mathrm{ml}, 0.81 \mathrm{mg} \mathrm{GAE} / \mathrm{ml}$, $1961.20 \mu \mathrm{g} \mathrm{TE} / \mathrm{ml}$, where degradation is observable due to exposure to high temperatures, but keeping a high ratios of these functional compounds which is very desirable in order to use the natural dyes as substitutes of artificial ones, and is a promissory source of functional compounds for increasing nutritional values into food products.
\end{abstract}

Keywords-Zea mays L., natural dyes, functional properties, antioxidantes.

\section{INTRODUCTION}

Currently there is a wide range of food products containing natural extracts, in order to strengthen or add endogenous or exogenous bioactive components. One of the most used technological strategies for development of functional foods is based on the food versatility to modify its composition, allowing changes in formulation and consequently about presence of ingredients in order to confer attributes to the product increasing healthy properties [14]. In the latter case, purple corn is found as a botanical source from which a natural colorant can be obtained, capable of providing color to food, cosmetic and pharmaceutical products, increasing functional compounds content.

Purple corn is a pigmented variety of Zea mays L., which grains and cob are purple due to presence of natural dyes. It is widely consumed in Latin America, mainly in Peru and Bolivia [5]. The commercial interest of purple corn is based on its anthocyanins content mainly in the cob, which is the reason of its characteristic color and makes it an alternative to use instead of artificial dyes. Also, anthocyanins, are responsible for antioxidant capacity, so usual consumption of these products, would bring potential health benefits [6].

Digital Object Identifier (DOI): http://dx.doi.org/10.18687/LACCEI2018.1.1.290 ISBN: 978-0-9993443-1-6

ISSN: $2414-6390$
In order to obtain anthocyanins is necessary to extract these bioactive compounds by exposure or contact to different solvents (water, ethanol, methanol or other). Likewise, control of the extraction temperature, contact time and medium $\mathrm{pH}$ must be taken into account [8][13]. Beyond establishing the proper conditions for extraction of purple corn anthocyanins, is mandatory to stabilize them; therefore, the most suitable method for obtaining stable bioactive compounds from extracts is by spray drying [2]. Even so, it is a technique that tends to degrade bioactive compounds whether these are not protected from high temperatures [4]. To reduce this phenomenon, microencapsulation of active ingredients is common, making use of substances with polymeric nature, such as: DE: 10-23 Maltodextrin, Carboxymethylcellulose (CMC), Gum arabic, etc., which purpose will be provide physical stability to bioactive compounds when are in contact with hot air [2][4]. Therefore, recovery of bioactive compounds and encapsulation yield will depend on the extraction method, encapsulant ratio, type of encapsulant and the operating conditions during spray drying. The application of purple corn dye powder has been studied as a food color in several food products, with a marked added value [1][8].

Hence, the objective of the study was to evaluate changes in anthocyanin content and some of its functional properties during the production of purple corn dye powder at pilot scale. The purple corn dye will be considered a functional additive in the development of instant beverages, as a increaser of natural antioxidants, as a proposal for the control of hypertension in adults.

\section{MATERIALS \& METHODS}

\section{A. Processing of purple corn dye powder at a pilot scale.}

The purple corn cobs (Zea Mays L.) were purchased at a local market in the district of San Miguel (Lima); those cobs which have presented moulds and a moisture content higher than $15 \%$ were discarded. Then, its initial content of total anthocyanins was characterized [6], total phenols and antioxidant capacity.

The cobs were subjected to the sequence of operations in Figure 1. The solid-liquid extraction operation considered a water ratio of $1: 10$, which was acidified with citric acid at $\mathrm{pH}$ 3.0. Then it was concentrated under vacuum $(-0.8 \mathrm{bar})$ up to volume reduction greater than $50 \%$ (or up to $3.3-3.6 \%$

16 $^{\text {th }}$ LACCEI International Multi-Conference for Engineering, Education, and Technology: "Innovation in Education and Inclusion”, 19-21 July 2018, Lima, Peru. 
total solids). Finally, it was spray-dried, considering a hot air inlet-temperature of $150^{\circ} \mathrm{C}$, feed flow of $0.75 \mathrm{~L} . \mathrm{h}^{-1}$ and a proportion of Maltodextrin DE10 (encapsulant) of 5 and $10 \% \mathrm{WM}$.

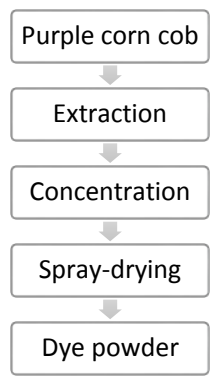

Figure 1. Flow diagram of processing of purple corn to obtain dye powder.

During each process stage, an extract sample was taken for the quantification of total anthocyanins, total phenols and antioxidant capacity.

\section{B. Determination of Total Anthocyanins (TA)}

To determine the content of Total Anthocyanins, Differential $\mathrm{pH}$ method was used [6]. The extracts were diluted in distilled water up to 200 times to allow the application of the methods. These dilutions were centrifuged at 3500 RPM for 10 minutes, separating the supernatant and being collected in amber bottle for the different analyses. Then a $100 \mu \mathrm{L}$ aliquot of the supernatant was taken and placed in test tubes containing $900 \mu \mathrm{L}$ of buffer $\mathrm{pH}: 1$ and 4.5 , proceeding to store in the dark for $10 \mathrm{~min}$. Next, readings was taken in the spectrophotometer at the maximum absorbance obtained from a previously performed spectral scan, and at $700 \mathrm{~nm}$. The content of total anthocyanins was determined with the following equation:

$$
\mathrm{A}=(\mathrm{Amax}-\mathrm{A} 700 \mathrm{~nm}) \mathrm{pH} 1-(\mathrm{Amax}-\mathrm{A} 700 \mathrm{~nm}) \mathrm{pH} 4.5 \ldots \text { (Eq.1) }
$$

The content of monomeric anthocyanins was determined with the following equation:

$$
(\mathrm{mg} / \mathrm{g} \mathrm{BS})=(\mathrm{A} \times \mathrm{MW} \times \mathrm{DF} \times 1000) /(\mathcal{E} \times 1 \times \mathrm{m}) \ldots(\mathrm{Eq} .2)
$$

Where: A: Obtained Absorbance, MW: Molecular Weight (449.2 g/mol), $\varepsilon$ : Molar extinction coeffcient 26,900 (mol-cm/g), DF: Dilution factor, M: Sample mass (dry basis).

\section{Determination of Total Phenolic Content (TPC)}

In order to determine the content of TPC, the FolinCiocalteu method was adapted [24]. Pouring in test tubes $0.5 \mathrm{~mL}$ of water for the blank and $0.5 \mathrm{~mL}$ of the dilution of the previously obtained extract; then $2.5 \mathrm{~mL}$ of diluted $10 \%$ Folin's solution was added and homogenized for 2 minutes. Subsequently, $2 \mathrm{~mL}$ of $7.5 \%$ sodium carbonate solution was added to each test tube and homogenized in a similar manner as the previously explained. The test tubes were then placed in a thermostatic bath at $45^{\circ} \mathrm{C}$ for a period of 15 minutes. After that time, the thermostat temperature was lowered to $30{ }^{\circ} \mathrm{C}$ and 15 minutes were waited until the reading was performed at $765 \mathrm{~nm}$ in a ThermoFisher spectrophotometer (Genesys 20, USA). The calibration curve was performed with standard Gallic Acid (Merck, Germany) at known concentrations (0-100 ug / ml).

\section{Determination of Antioxidant Capacity (AC)}

The ABTS method proposed by Ref. [23] was adapted to determine the antioxidant capacity. This trial was based on the ability to collect the cation of the ABTS + radical. The radical cation was prepared by mixing $7 \mathrm{mM}$ of the ABTS standard solution with $2.45 \mathrm{mM}$ potassium persulfate in concentration [1: $1, \mathrm{v} / \mathrm{v}]$, and the mixture was stored for 16 hours until the reaction is complete and the absorbance is stable. The solution was diluted with ethanol up to obtain readings of $0.700 \pm 0.005$ of absorbance at $734 \mathrm{~nm}$ to perform the measurements. The spectrophotometric test was carried out with $0.9 \mathrm{ml}$ of ABTS + and $0.1 \mathrm{ml}$ of the previously obtained extract dilution. The decrease in absorbance at different concentrations was calculated using the following equation:

$$
\mathrm{E}(\%)=(\mathrm{Ac}-\mathrm{At}) /(\mathrm{Ac}) \times 100 \ldots(\mathrm{Eq} .3)
$$

Where: At is absorbance of tested sample, Ac is absorbance of ABTS+ control.

\section{E. Evaluation of purple corn dye poder physical properties}

Moisture was determined by the indirect gravimetric method by drying [25], using a Memmert stove (UN30, Germany) at a temperature of $135^{\circ} \mathrm{C}$ for 2 hours.

\section{RESULTS \& DISCUSSIONS}

\subsection{Functional characterization of raw material}

In Table I, the total anthocyanins content, total phenolic content and antioxidant capacity of the purple corn cob considered as raw material is shown.

TABLE I

SOME FUNCTIONAL PROPERTIES OF PURPLE CORN

\begin{tabular}{|l|c|}
\hline & $\begin{array}{c}\text { Functional content of Zea } \\
\text { mays L. cob }\end{array}$ \\
\hline TPC $(\mathrm{mg} \mathrm{GAE} / \mathrm{g} \mathrm{DM})$ & $127.47 \pm 0.59$ \\
\hline $\mathrm{TA}(\mathrm{mg}$ TA/g DM$)$ & $125,76 \pm 1,23$ \\
\hline $\mathrm{AC}$ ABTS $(\mathrm{EC} 50[\mu \mathrm{g} \mathrm{TE} / \mathrm{g}])$ & $72.15 \pm 1.16$ \\
\hline
\end{tabular}

\subsection{Extraction yield of purple corn dye at pilot scale}

The process indicated in Figure 1 was followed. The solid-liquid extraction phase of the purple corn cob dye was carried out by exhaustion in a $50 \mathrm{~L}$ cauldron, where total anthocyanin content was found as an operation indicator (see Table II). Ref. [9] and Ref. [10] have reported recoveries of -TA in purple corn between 57 and $89 \%$. 
TABLE II

CONCENTRATION OF TOTAL ANTHOCYANINS DURING EXTRACTION IN CAULDRON

\begin{tabular}{|c|c|}
\cline { 2 - 2 } \multicolumn{1}{c|}{} & TA Content $(\mathrm{mg} / \mathrm{mL})$ \\
\hline Raw Material & $1,193 \pm 0,001$ \\
\hline Extraction 1 & $0,804 \pm 0,001$ \\
\hline Extraction 2 & $0,239 \pm 0,000$ \\
\hline Extraction 3 & $0,087 \pm 0,000$ \\
\hline Extraction 4 & $0,034 \pm 0,000$ \\
\hline Extraction 5 & $0,029 \pm 0,000$ \\
\hline
\end{tabular}

Ref. [17] optimized the extraction process of anthocyanins in purple corn (Zea mays L.) using colorimetry methods, finding that methanol extraction $(80 \%)$, acidified with citric acid $(1 \%)$ it turned out to obtain $5.90 \pm 0.23 \mathrm{mg} \mathrm{TA} / \mathrm{g}$ sample; this being lower than that found in the present investigation (38.74 $\pm 0.38 \mathrm{mg}$ TA/g sample WM). Ref. [18] in their study of phenolic antioxidant kinetics of Andean purple corn and red pulp sweet potato, they obtained closer results $(16.42 \pm 0.92 \mathrm{mg} \mathrm{TA} / \mathrm{g}$ sample). Table 2 shows the TA concentrations quantified from the extractions in aqueous medium ( $1 \%$ citric acid), which were carried out until the mentioned pigment was exhausted, being a total of five extractions, where the two former represent $87.37 \%$ of the total extracted; similar results were found by Ref. [17]; using $80 \%$ methanol with $1 \%$ citric acid, they obtained $93.43 \%$ of the total extracted in the first two extractions. On the other hand, Ref. [16] using a mixture of $60 \%$ ethanol acidified with $0.5 \%$ of $\mathrm{HCl}$, also obtained in the second extraction $87.9 \%$ of the total extracted; amount similar to that of the present study. Recovery of anthocyanins after spray-drying, in the present study a $70.61 \pm 1.02 \%$ was obtained. In Ref. [19], results of extraction, quantification and drying by atomization of purple corn extracts were recovery percentages that fluctuate between $57.3 \pm 8.9 \%$ and $89.4 \pm 3.9 \%$.

About TPC (mgGAE/g sample), Ref. [23] in their study of characterization of purple corn (Zea mays L.) obtained a maximum of 40,584 $\mathrm{mg}$ GAE/g sample, higher than those reported in the present study $(13.77 \pm 0.12 \mathrm{mg}$ GAE/g sample WM). Moreover, Ref. [20] obtained 76,962 mg GAE / g sample, and those reported were also higher. From the spray-dried extracts $17.46 \pm 0.17 \mathrm{mg}$ GAE / g sample was obtained, below than reported by Ref. [21] (135 mg of TPC / $g$ ethyl acetate fraction), this is due to type of solvent used; where ethyl acetate is wide used for characterization solvent; on the other hand, water is better to be used on an intermediate product in industry.

\subsection{Effects of processing on functional properties of purple corn dye}

Exposure to high temperatures during concentrate or atomization tends to have a direct effect on some of the functional properties of purple corn dye, as detailed in Table III.
TABLE III

CHANGES OF THE FUNCTIONAL PROPERTIES DURING PROCESS

\begin{tabular}{|l|c|c|c|c|c|c|}
\cline { 2 - 7 } \multicolumn{1}{c|}{} & \multicolumn{2}{c|}{ TA $(\mathrm{mg} / \mathrm{mL})$} & \multicolumn{2}{c|}{ TPC $(\mathrm{mg} / \mathrm{mL})$} & \multicolumn{2}{c|}{$\begin{array}{c}\text { AC } \\
\text { EC50 }[\mu \mathrm{g} \text { TE/g] }\end{array}$} \\
\cline { 2 - 7 } & Before & After & Before & After & Before & After \\
\hline Concentrate & 0,53 & 0,62 & 1,81 & 2,26 & 787.17 & 2471.77 \\
\hline Spray-dried & 0,52 & 0.37 & 1,97 & 0.87 & 2471.77 & 1961.20 \\
\hline
\end{tabular}

3.4 Physical and functional properties of purple corn dye powder.

The results obtained in the present research are summarized in Table IV.

TABLA IV

PHYSICAL AND FUNCTIONAL PROPERTIES OF PURPLE CORN DYE POWDER

\begin{tabular}{|l|c|}
\cline { 2 - 2 } \multicolumn{1}{c|}{} & Means \pm SD \\
\hline TPC $(m g$ GAE/g DM) & $18,43 \pm 0,27$ \\
\hline TA $(\mathrm{mg}$ AT/g DM) & $7,71 \pm 0,14$ \\
\hline AC ABTS $[\mu \mathrm{g} \mathrm{TE} / \mathrm{ml}]$ & $1961.2 \pm 0.98$ \\
\hline Moisture $(\%)$ & $3,83 \pm 0,07$ \\
\hline
\end{tabular}

The results of purple corn AC were studied by ABTS+ proposed by Ref. [23] was $72.15 \mu \mathrm{g}$ TE/g for the cob. Ref. [12] obtained similar results in samples characterized by purple corn by ABTS+ (up to $87.09 \mu \mathrm{g} \mathrm{TE} / \mathrm{g}$ ). Ref. [15], studied different methods of obtaining extracts with different solvents (methanol and water) and a mixture of both in different concentrations; results were obtained to a similar value to those obtained; samples taken with water were greater than methanol-water; in the same way the results obtained in the present investigation are delimited where the concentrates are by aqueous extraction $\left(\mathrm{H}_{2} \mathrm{O}\right.$ $100 \%$ ) are greater than those characterized by the methodology with methanol-water. Regarding its aqueous extract, $787.17 \mu \mathrm{g} \mathrm{TE} / \mathrm{g}$ were obtained, and for the purple corn concentrate $2471.77 \mu \mathrm{g} \mathrm{TE} / \mathrm{g}$; while spray-dried powder of the purple corn extract obtained 1961.2 $\pm 0.98 \mu \mathrm{g}$ $\mathrm{TE} / \mathrm{g}$, mantaining a high value of recovery (79\%). Degradation between the concentrated solution and the spray-dried powder is remarkably clear. Ref [3] indicates that once in the antioxidant capacity after a heat treatment; where it was a $28 \%$ loss after nixtamalizing, between 37 and $55 \%$ after an extrusion; in present investigation degradation is notorious and may be associated with the loss of phenolic compounds during processing [7][11][19].

\section{CONCLUSION}

Functional properties were determined by several essays during the tests. Results shown that degradation is observable during processing, due to exposure to high temperatures. Nevertheless high ratios of these functional compounds were found after processing and results are comparable with several authors, which is very desirable in order to use the natural dyes in formulations instead of artificial dyes. For these reasons purple corn cob dye 
powder extracted by water as solvent is a cheap promissory source of natural dye and functional compounds, due to its high total anthocyanins and phenolic content which leads to a high antioxidant capacity, and no-traces of chemical solvents, due to these can be used to increase nutritional value to whatsoever food product is manufactured.

\section{ACKNOWLEDMENT}

The authors thank the National Innovation Program for Competitiveness and Productivity - Innovate Peru (Contract 470-INNOVATEPERU-PITEI-2016).

\section{REFERENCES}

[1] Acevedo Castillo, A. R. (2003). Efecto de la temperatura y un copigmento en la estabilidad de antocianinas de la col morada en una bebida. Universidad de las Américas Puebla.

[2] Cai, Y., \& Corke, H. (2000). Production and Properties of Spray-dried Amaranthus Betacyanin Pigments. Journal of food science, $1248-1252$.

[3] Del Pozo-Insfran D, Brenes CH, Serna Saldivar SO, Talcott ST. (2006). Polyphenolic and antioxidant content of white and blue corn (Zea mays L.) products. Food Res Intl 39:696-703.

[4] Ersus, S., \& Yurdagel, U. (2007). Microencapsulation of anthocyanin pigments of black carrot (Daucuscarota L.) by spray drier. Journal of Food Engineering, 805-812.

[5] Escribano, M., Santos, C., \& Rivas. (2004). Anthocyanins in cereals. Journal of Chromatography A, 129-141.

[6] Giusti, M., \& Wrolstad, R. (2003). Acylated anthocyanins from edible sources and their applications in food systems. Biochemical Engineering Journal, 217-225.

[7] Harakotr B., Suriharn B., Tangwongchai, R., Scott, M., Lertrat K.(2014). Anthocyanin, phenolics and antioxidant activity changes in purple waxy corn as affected by traditional cooking, Food Chemistry, Volume 164, Pages 510-517.

[8] Jing, P., \& Giusti, M. (2007). Effects of Extraction Conditions on Improving the Yield and Quality of an Anthocyanin-Rich Purple Corn (Zea mays L.) Color Extract. Journal of food science, 363-368.

[9] Lao, F. (2016). Purple Corn (Zea mays L.) Cob Anthocyanins: Extraction, Quantification, Spray Drying and Complexation with Proteins. The Ohio State University, 222.

[10] Lao, F., \& Giusti, M. (2017). The effect of pigment matrix, temperature and amount of carrier on the yield and final color properties of spray dried purple corn (Zea mays L.) cob anthocyanin powders. Food Chemistry, 376-382.

[11] Lao, F., Sigurdson, G., Giusti, M. (2017). Health Benefits of Purple Corn (Zea mays L.) Phenolic Compounds. Comprenhensive Reviews in Food Science and Food Safety. Volume 16 (2), Pages 234-246

[12] Lopez-Martinez, L., Oliart-Ros, R., Valerio-Alfaro, G., Chen-Hsien Lee, Parkin, K., Garcia, H. (2009). Antioxidant activity, phenolic compounds and anthocyanins content of eighteen strains of Mexican maize, LWT - Food Science and Technology, Volume 42, Issue 6, Pages 1187-1192

[13] Yang, Z., \& Zhai, W. (2010). Optimization of microwaveassisted extraction of anthocyanins from purple corn (Zea mays L.) cob and identification with HPLC-MS. Innovative Food Science \& Emerging Technologies, 470-476.

[14] Jiménez-Colmenero, Francisco. (2013). Emulsiones múltiples: compuestos bioactivos y alimentos funcionales. Nutrición Hospitalaria, 28(5), 1413-1421. https://dx.doi.org/10.3305/nh.2013.28.5.6673

[15] Ramos-Escudero, F., Muñoz, A. M., Alvarado-Ortíz, C., Alvarado, Á., \& Yáñez, J. A. (2012). Purple Corn (Zea mays L.) Phenolic Compounds Profile and Its Assessment as an
Agent Against Oxidative Stress in Isolated Mouse Organs. Journal of Medicinal Food, 15(2), 206-215.

[16] Mendoza, Evelyn , Cecilia Curi , Virginia Mercado, y Juan Alvarado . «Encapsulation, characterization and thermal stability of anthocyanins from Zea Mays L. (Purple Corn).» Revista Boliviana de Química, 2016: 183-189.

[17] Yang , Zhendong , Gongjian Fan, y Zhenxin Gu. «Optimization extraction of anthocyanins from purple corn (Zea mays L.) cob using tristimulus colorimetry.» European Food Research and Technology, 2008: 409-415.

[18] Cevallos, Bolivar, y Luis Cisneros. «Stoichiometric and Kinetic Studies of Phenolic Antioxidants from Andean Purple Corn and Red-Fleshed Sweetpotato.» Journal of agricultural and food chemistry, 2003: 3313-3319.

[19] Lao, Fei. «Purple Corn (Zea mays L.) Cob Anthocyanins: Extraction, Quantification, Spray Drying and Complexation with Proteins.» The Ohio State University, 2016: 222pp.

[20] Gorriti, A., Arroyo, J., Negrón, L., Jurado, B., Purizaca, H., Santiago, I., Taype, E., Quispe, F. (2009). Antocianinas, fenoles totales y actividad antioxidante de las corontas de maíz morado (Zea mays L.): Método de extracción. Boletín Latinoamericano y del Caribe de Plantas Medicinales y Aromáticas - BLACPMA, 2009; 8(6): 509-518.

[21] Pedreschi, R., Cisneros-Zevallos, L.. Phenolics profiles of Andean purple corn (Zea mays L.). Food Chemistry, 2007; 100: 956-963.

[22] Quispe, F., Arroyo, K., Gorriti, A. Características morfológicas y químicas de 3 cultivares de maíz morado (zea mays 1.) en Arequipa - Perú , Rev Soc Quím Perú. 77 (3) 2011

[23] Shalaby, E., Shanab, S. Comparison of DPPH and ABTS assays for determining potential of water and methanol extracts of Spirulina platensis. Indian Journal of Geo.Marine Sciences. 42 (5). 2013. Pp. 556-564.

[24] Singleton, V., Rossi, J. Colorimetry of Total Phenolics with Phosphomolybdic-Phototungstenic Acid Reagents. UC Davis. 1965.

[25] AOAC. Official Methods of Analysis. 930.15, 2005. 